\title{
Application of the Oxic-Settling-Anaerobic Process in a Membrane Bioreactor for Excess Sludge Reduction
}

\author{
T. Silva de Oliveira $\left.{ }^{(}\right)$, S.F. Corsino, D. Di Trapani, \\ and M. Torregrossa
}

\begin{abstract}
Department of Civil, Environmental, Aerospatial Engineering and Material, University of Palermo, Viale delle Scienze Building 8, 90128 Palermo, Italy
\end{abstract}

\begin{abstract}
The main goal of this study was the evaluation of the excess sludge reduction in a MBR for biological nitrogen removal (BNR) through the implementation of the Oxic-Settling-Anaerobic (OSA) process. For this purpose, a MBR pilot plant ( $42 \mathrm{~L}$ volume) was realized according to a pre-denitrification scheme. The whole experimentation was divided into two periods, named Period 1 and Period 2, respectively. In Period 1 the pilot plant was started-up and the excess sludge production was evaluated. In Period 2 the plant configuration was partially modified by inserting an anaerobic reactor into the return activated sludge (RAS) line to realize an OSA configuration. In Period 1, the $\mathrm{Y}_{\mathrm{obs}}$ resulted equal to $0.39 \mathrm{gVSS} \mathrm{g}^{-1} \mathrm{COD}_{\text {removed }}$, in accordance with the reference values for MBR plants reported in the literature (Wang et al. 2013). Similarly, all the kinetic and stoichiometric parameters, for both autotrophic and heterotrophic biomass, resulted in line with those reported in a MBR with a pre-denitrification scheme (Lubello et al. 2009). In contrast, in Period 2 the Yobs showed a significant decrease, reaching a pseudo steady-state value of $0.17 \mathrm{gVSS} \mathrm{g}^{-1} \mathrm{COD}_{\text {removed }}$ at the end of the experiments, highlighting a reduction of 55\% compared to Period 1.
\end{abstract}

Keywords: Membrane bioreactor $\cdot$ Excess sludge minimization $\cdot$ OSA

\section{Introduction}

In the last years, biological treatment has become one of the most adopted alternatives for wastewater treatment. Nevertheless, besides its good performances, there are some issues that still deserve attention, i.e. the operating costs that concern mainly the disposal of the excess sludge production. According to the literature, the European Union annually produces over 10 million tons of waste activated sludge (WAS) and the United States currently generates about 8.2 million tons of dry WAS per year (Wang et al. 2012). The European Waste Framework Directive (2008/98 CE) highlighted that the minimization at the source must be a priority.

Nevertheless, the treatment and disposal of excess sludge is expensive. Usually, it accounts about $30-60 \%$ of the total operating cost in a conventional activated sludge (CAS) treatment plant (Saby et al. 2003). Some authors have explored in the last years different solutions to reduce the excess sludge production, but most of the known alternatives imply high energy consumption that raises the costs, thus making them difficultly applicable (Foladori et al. 2010). 
Among these alternatives, the use of the Oxic-Settling-Anaerobic (OSA) process have been widely studied, mainly in CAS systems (Torregrossa et al. 2012). However, few authors have combined the OSA system with Membrane-Bioreactors (MBRs). Therefore, there are still several challenges to identify the optimal plant configuration, since it is not trivial to find a good balance between the necessary sludge production and the reduction of the excess production.

Semplante et al. (2014) in a review paper highlighted that a plant configuration with anoxic, aerobic and anaerobic alternation can achieve $50 \%$ of excess sludge reduction, even in CAS configuration. By including the use of MBR for the liquid-solid separation, this rate could improve. MBRs have four mechanisms for sludge minimization: biological maintenance metabolism, lysis-cryptic growth, predation of bacteria and uncoupling metabolism, also MBRs are operated under long sludge retention time (SRT) resulting in low food/microorganisms $(\mathrm{F} / \mathrm{M})$ ratio and a high mixed liquor suspended solids (MLSS) concentration (Wang et al. 2013).

Bearing in mind the above considerations, the main goal of this study was the evaluation of the excess sludge reduction in a MBR for biological nutrients removal by means of implementation of the OSA process.

\section{Materials and Methods}

In this study, the excess sludge production in a submerged MBR pilot plant for biological nutrients removal was monitored. The MBR pilot plant (42 L) was realized according to a pre-denitrification scheme. Particularly, the pilot plant consisted of an anoxic $(18 \mathrm{~L})$ and an aerobic tank $(24 \mathrm{~L})$. The solid-liquid separation phase was achieved by an ultrafiltration hollow-fiber membrane module (PURON ${ }^{\circledR}$ Single bundle Demo, nominal pore size $0.03 \mu \mathrm{m}$, membrane area $0.47 \mathrm{~m}^{2}$ ) located within the aerobic tank (thus, in a submerged configuration). The filtration cycle had a duration of 6 min, divided into $5 \mathrm{~min}$ of permeate suction and $1 \mathrm{~min}$ of backwashing. The membrane backwashing was performed by pumping a volume of permeate back through the membrane fibers from the Clean In Place (CIP) tank.

The MBR was seeded with activated sludge collected from a wastewater treatment plant with a conventional activated sludge scheme (inoculum TSS equal to $3 \mathrm{gTSS} \mathrm{L}^{-1}$ ).

The whole experimentation was divided into two periods, named Period 1 and Period 2 , respectively. In Period 1, the pilot plant was started-up and the excess sludge production was evaluated. The MBR was fed with synthetic wastewater through a peristaltic pump from a feeding tank to the anoxic reactor, with a flow rate approximately equal to $2.3 \mathrm{Lh}^{-1}$. Then, the mixed liquor flowed by gravity to the aerobic/membrane reactor where a net permeate flow rate close to $2.3 \mathrm{Lh}^{-1}$ was extracted through the membrane module. The mixed liquor was pumped to the anoxic tank via an internal recycling with a flow rate equal to $11.5 \mathrm{Lh}^{-1}$, corresponding to a nitrate recycling ratio of 5:1. This period lasted about 4 weeks, until steady-state conditions were reached.

In Period 2, the plant configuration was partially modified by inserting an anaerobic reactor into the return activated sludge (RAS) line to realize an OSA configuration. Particularly, in addition to the configuration above described, a fraction of the mixed liquor was pumped from the aerobic tank to the OSA reactor $(13.8 \mathrm{~L})$ with a flow rate 
equal to $2.3 \mathrm{Lh}^{-1}$ and then it was recycled to the anoxic reactor. The hydraulic retention time (HRT) in the OSA reactor was imposed equal to $6 \mathrm{~h}$ (about one third of the HRT of the entire pilot plant).

The anoxic and the OSA reactors were continuously mixed by a vertical axis mixer. In the aerobic/membrane reactor, the oxygen was supplied by a blower connected to a diffuser porous stone placed at the bottom of the reactor.

The synthetic wastewater was composed of (in $100 \mathrm{~L}$ ): $35 \mathrm{~g}$ of potato starch, $4.5 \mathrm{~g}$ of peptone, $15 \mathrm{~g}$ of sodium acetate $\left(\mathrm{CH}_{3} \mathrm{COONa}\right), 4 \mathrm{~g}$ of urea $\left(\mathrm{CH}_{4} \mathrm{~N}_{2} \mathrm{O}\right), 14.5 \mathrm{~g}$ of ammonium chloride $\left(\mathrm{NH}_{4} \mathrm{Cl}\right)$ and $6 \mathrm{~g}$ of dipotassium phosphate $\left(\mathrm{K}_{2} \mathrm{HPO}_{4}\right)$. The main influent wastewater characteristics are summarized in Table 1.

The influent wastewater, the mixed liquor inside the anoxic, aerobic, OSA tanks and the permeate were sampled three times a week for the physical-chemical analyses.

Table 1. Summary of the main wastewater influent characteristics

\begin{tabular}{l|l|l}
\hline & MBR & Unit \\
\hline Total COD & $580 \pm 15$ & $\left(\mathrm{mg} \mathrm{L}^{-1}\right)$ \\
\hline Soluble COD & $435 \pm 23$ & $\left(\mathrm{mg} \mathrm{L}^{-1}\right)$ \\
\hline Total Nitrogen & $63 \pm 8$ & $\left(\mathrm{mg} \mathrm{L}^{-1}\right)$ \\
\hline $\mathrm{NH}_{4}-\mathrm{N}$ & $57 \pm 4$ & $\left(\mathrm{mg} \mathrm{L}^{-1}\right)$ \\
\hline $\mathrm{PO}_{4}-\mathrm{P}$ & $12 \pm 2$ & $\left(\mathrm{mg} \mathrm{L}^{-1}\right)$ \\
\hline $\mathrm{BOD}_{5}$ & $386 \pm 12$ & $\left(\mathrm{mg} \mathrm{L}^{-1}\right)$ \\
\hline
\end{tabular}

In particular, the biological performances were monitored through the total chemical oxygen demand (tCOD), soluble COD (sCOD), ammonium nitrogen $\left(\mathrm{NH}_{4}-\mathrm{N}\right)$, nitrate nitrogen $\left(\mathrm{NO}_{3}-\mathrm{N}\right)$, total nitrogen (TN), Biochemical Oxygen Demand (BOD) analyses in the influent wastewater, in the anoxic and aerobic supernatant and in the permeate. Moreover, total suspended solids (TSS), volatile suspended solids (VSS) and sludge features (granulometry, viscosity, hydrophobicity, sludge volume index (SVI), extracellular polymeric substances (EPS) and dewaterability) were performed once a week in all the reactors. All the chemical-physical analyses were carried out according to the Standard Methods (APHA 2005). In order to evaluate the effect of the OSA process implementation on the biomass biological diversity, microscopic observations were carried out for the identification of filamentous bacteria and other microorganisms.

The observed heterotrophic yield coefficient $\left(\mathrm{Y}_{\mathrm{obs}}\right)$, referred to the whole system, was evaluated through mass balances between sludge withdrawn, sludge production and solids in the effluent, dividing by the cumulated TCOD removed, according to the procedure reported by Torregrossa et al. (2012).

In addition, respirometric batch experiments were performed to evaluate both the autotrophic and heterotrophic kinetic parameters. Furthermore, $\mathrm{pH}$, dissolved oxygen (DO), oxidation-reduction potential (ORP) and temperature were also monitored in each tank by means of specific probes. Lastly, in order to estimate the excess sludge production, the specific observed heterotrophic yield coefficient (Yobs), referred to the whole system, was calculated on the basis of mass balances between sludge withdrawn and sludge production, dividing by the cumulated SCOD removed. 


\section{Results and Discussion}

The achieved results highlighted excellent performances in terms of organic matter removal. Indeed, the total COD removals (average values) were 95 and $98 \%$ in Period 1 and Period 2, respectively. Even the biological COD removal (i.e. evaluated upstream membrane filtration) was particularly high, with an average value approximately equal to $94 \%$ throughout the experiments. The observed data confirmed the high robustness of MBRs systems towards the removal of the organic substrates.
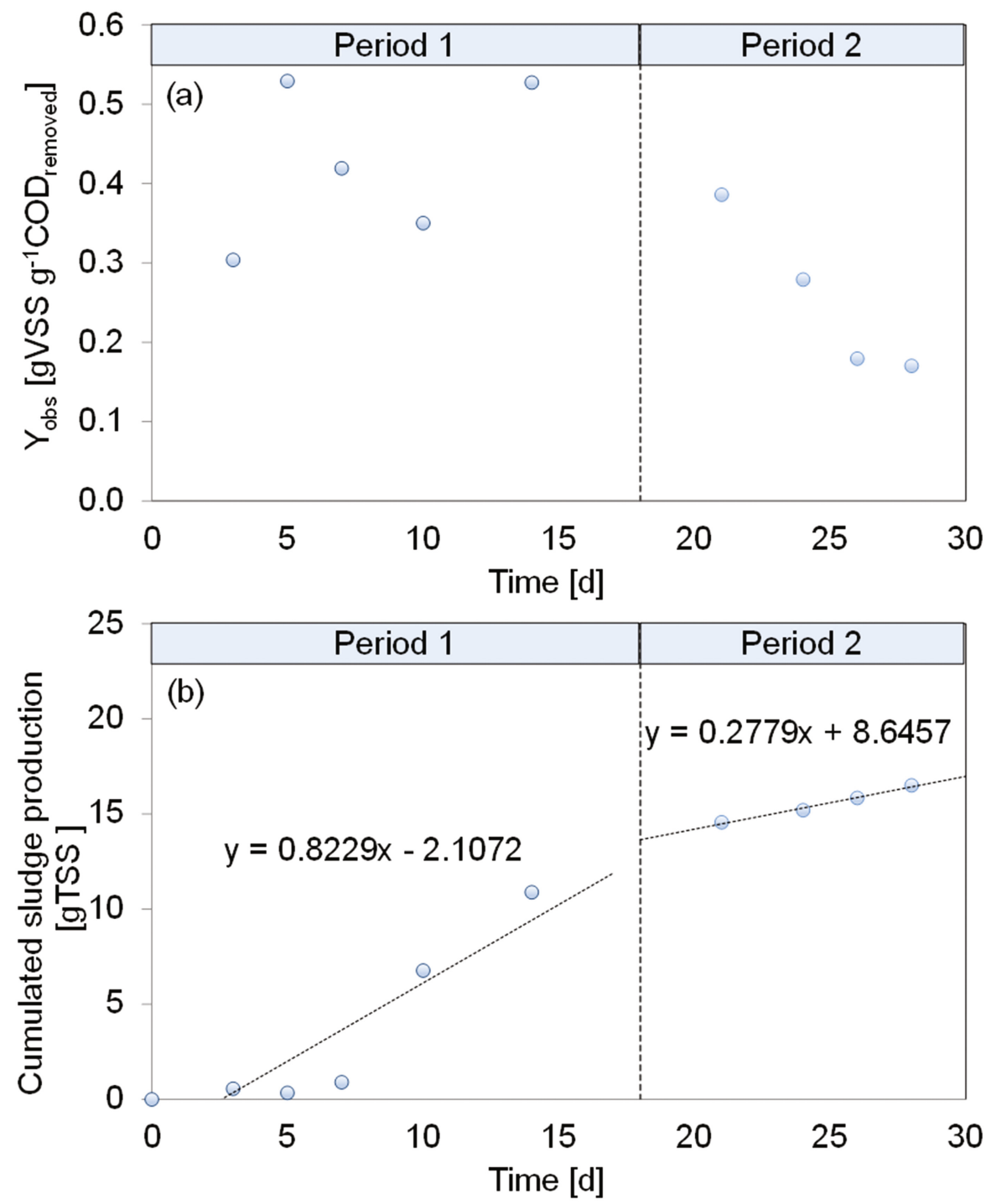

Fig. 1. Profiles of $Y_{o b s}$ (a) and cumulated excess sludge production (b) throughout experiments 
Concerning the reduction of sludge production, Fig. 1a depicts the assessed $\mathrm{Y}_{\mathrm{obs}}$ values, whilst Fig. $1 \mathrm{~b}$ reports the cumulated sludge produced throughout the experiments.

From the observation of data reported in Fig. 1a, the Yobs decreased from an average value of $0.39 \mathrm{gVSS} \mathrm{g}^{-1} \mathrm{COD}_{\text {removed }}$ in Period 1 to a steady state value of 0.17 $\mathrm{gVSS} \mathrm{g}^{-1} \mathrm{COD}_{\text {removed }}$ at the end of Period 2, corresponding to a $55 \%$ net reduction. It is worth noting that such a reduction was achieved with a HRT of the OSA reactor of $6 \mathrm{~h}$ only; a further increase of the HRT would likely increase this reduction, thus enhancing to reach a potential "zero net growth".

As shown in Fig. 1b, after the change of the pilot plant configuration, characterized by the introduction of the OSA reactor, the net sludge production significantly decreased compared to what observed in Period 1. Indeed, in Period 1 the sludge production was $0.83 \mathrm{gTSS} \mathrm{d}^{-1}$, while in Period 2 it decreased down to $0.28 \mathrm{gTSS} \mathrm{d}^{-1}$, thus confirming the effectiveness of the OSA configuration.

In terms of biomass biokinetic activity, evaluated through respirometry, Table 2 summarizes the main kinetic/stoichiometric values achieved throughout the experiments.

Table 2. Average values of the main kinetic and stoichiometric parameters measured during experiments

\begin{tabular}{l|r|r}
\hline Plant configuration & MBR & MBR-OSA \\
\hline Heterotrophic & 0.54 & 0.44 \\
\hline $\mathrm{Y}_{\mathrm{H}}\left[\mathrm{g} \mathrm{VSS} \mathrm{g} \mathrm{COD}^{-1} \mathrm{CO}\right.$ & 0.78 & 0.63 \\
\hline $\mathrm{Y}_{\mathrm{H}}\left[\mathrm{mg} \mathrm{COD} \mathrm{mg}^{-1} \mathrm{COD}\right]$ & 2.58 & 2.10 \\
\hline$\mu_{\mathrm{H}, \max }\left[\mathrm{d}^{-1}\right]$ & 2.74 & 4.58 \\
\hline $\mathrm{K}_{\mathrm{S}}\left[\mathrm{mg} \mathrm{COD} \mathrm{L}^{-1}\right]$ & 26.69 & 29.57 \\
\hline $\mathrm{SOUR}_{\max }\left[\mathrm{mg} \mathrm{O}_{2} \mathrm{~g}^{-1} \mathrm{VSS} \mathrm{h}^{-1}\right]$ & \\
\hline Autotrophic & 0.19 & 0.21 \\
\hline $\mathrm{Y}_{\mathrm{A}}\left[\mathrm{g} \mathrm{VSS} \mathrm{g} \mathrm{NH}_{4}-\mathrm{N}\right]$ & 0.28 & 0.29 \\
\hline$\mu_{\mathrm{A}, \max }\left[\mathrm{d}^{-1}\right]$ & 3.22 & 2.88 \\
\hline $\mathrm{K}_{\mathrm{NH}}\left[\mathrm{mg} \mathrm{NH}_{4}-\mathrm{N} \mathrm{L}^{-1}\right]$ & 15.96 & 19.64 \\
\hline SOUR $_{\max }\left[\mathrm{mg} \mathrm{O}_{2} \mathrm{~g}^{-1} \mathrm{VSS} \mathrm{h}^{-1}\right]$ &
\end{tabular}

From the observation of Table 2, it is worth noting that the $\mathrm{Y}_{\mathrm{H}}$ values achieved through respirometry were slightly higher compared to the $\mathrm{Y}_{\mathrm{obs}}$ ones. This discrepancy is only apparent: indeed, the Yobs values were evaluated on the basis of mass balances, that took into account the biomass decay, differently from a respirometric batch test which duration is much more limited.

\section{Conclusions}

The present study explored the performance of an OSA-MBR pilot plant for the reduction of sludge production. The achieved results highlighted the high potentiality of this configuration, enhancing the reduction of the observed sludge yield up to $55 \%$. Moreover, the performances of the system in terms of organic matter removal 
efficiency were not significantly affected by the change in configuration, with a total COD removal of $98 \%$ in Period 2 (OSA configuration). Since the HRT of the OSA reactor was imposed at $6 \mathrm{~h}$ only, it is possible to assume that future research activities characterized by higher HRT values might enhance a further decrease of the excess sludge production.

\section{References}

Foladori P, Andreotolla G, Ziglio G (2010) Sludge reduction technologies in wastewater treatment plants. IWA Publishing. 380 p. ISBN 13: 9781843392781

Lubello C, Caffaz S, Gori R, Munz G (2009) A modified Activated Sludge Model to estimate solids production at low and high solids retention time. Water Res 43(18):4539-4548

Saby S, Djafer M, Chen G (2003) Effect of low ORP in anoxic sludge zone on excess sludge production in oxic-settling-anoxic activated sludge process. Water Res 37:11-20

Semblante G, Hai F, Ngo H, Guo W, You S, Price W (2014) Sludge cycling between aerobic, anoxic and anaerobic regimes to reduce sludge production during wastewater treatment: Performance, mechanisms, and implications. Biores Technol 155:395-409

Torregrossa M, Di Bella G, Di Trapani D (2012) Comparison between ozonation and the OSA process: analysis of excess sludge reduction and biomass activity in two different pilot plants. Water Sci Technol 66:185-192

Wang Z, Yu H, Ma J, Zheng X, Wu Z (2013) Recent advances in membrane bio-technologies for sludge reduction and treatment. Biotechnol Adv 31:1187-1199

Wang ZW, Mei XJ, Ma JX, Wu ZC (2012) Recent advances in microbial fuel cells integrated with sludge treatment. Chem Eng Technol 35(10):1733-1743 